\title{
The Quality of Accounting Earnings and Change in Political Power Map: Evidence from Indonesia
}

\author{
Iman Harymawan ${ }^{1, *}$, Dian Agustia $^{2}$, and Khusnul Prasetyo ${ }^{3}$ \\ ${ }^{1,2,3}$ Airlangga University, Indonesia
}

\begin{abstract}
This study investigates the earnings quality of politically connected firms listed in Indonesian Stock Exchange during 2006-2010. This study compare two definition (Soeharto Dependency Index (SDI) and Politically Exposed Person (PEP)) of political connections to capture the effect of the changes of political power map on the earnings quality of politically connected firms in Indonesia. The finding shows that the quality of accounting earnings of politically connected firms which were formerly closely related to President Soeharto in 1998 are not significantly different to other firms. Furthermore, when this study employ politically exposed person as a proxy of political connections, the findings shows that connected firms have significantly lower quality accounting earnings. Consistent with prior findings, this study shows that change in political power map in Indonesia affect the level of earnings quality of politically connected firms.
\end{abstract}

\section{INTRODUCTION}

In the annual survey of corruption perceptions, Transparency International rates Indonesia as one of the most corrupt countries on earth. Political power is one of the influential factors in many aspects in this country. Despite a number of recent media articles on the topic, prior studies have not examined the quality of accounting earnings for politically connected firms in Indonesia. Previous studies of connected firms in Indonesia look at stock returns following rumors about Soeharto's (former Indonesia President) health [1]. This study shows that firms that were close to Suharto suffered negative returns when bad news about the President's health hit the stock market. Leuz and Oberholzer-Gee [2] analyze how politically connected firms in Indonesia make strategic financing decisions. Their results suggest that foreign securities and close political connections are substitutes. They find that firms that close to Suharto were significantly less likely to have publicly traded securities abroad.

The results of international studies suggest that firms with political connections have lower quality accounting earnings [3]. Firms with political ties dislike the transparency and scrutiny because high levels of public scrutiny can be difficult to reconcile with political favors of often dubious legality [2]. However, whether this is the case for Indonesia and whether the quality of accounting earnings in Indonesia is influenced by the

* Corresponding author: harymawan.iman@feb.unair.ac.id 
change of structure of political power map is the focus of this paper. This study also further analyzes the quality of accounting earnings among politically connected firms (non-State Owned Enterprises (SOEs)), State-Owned Enterprises and non-politically connected firms for listed companies in Indonesia.

The first part of this paper examine the link between political connections and the quality of accounting earnings in Indonesia's listed companies using the Soeharto Dependency Index [1]. Leuz and Oberholzer-Gee [2] find that for firms which closely related to Soeharto tend to access to foreign securities due to the difficulty re-establishing connections with a new government when their patrons fall from power. Firms with foreign securities attract the attention of foreign analysts and the international press coverage [[4] ; [5]]. Due to the increase of public scrutiny, they also have to increase their transparency. The result of this paper support this view which shows that the quality of accounting earnings of firms which were formerly closely related to Soeharto is not significantly different to other firms during 2005-2010 due to change in political structure map. In respect of relation, the political connections dummy variable has negative relation to accounting quality variable. It is indicate that the quality of accounting earnings for firms which formerly closely related to Soeharto is relatively better than other firms.

In the second part, this study employ politically exposed person to define politically connected firms. This study find that firm with political connections is associated with a lower quality of accounting earnings. Interestingly, when we include State-owned Enterprise (SOE) as politically connected firms, we find that the quality of accounting earnings of politically connected firms is become higher. This finding shows that SOE in Indonesia have better quality of accounting earnings than firms which have politically exposed person as a board of directors. Overall, consistent with prior findings, these findings give us the notion that the changes of political power structure influence the quality of accounting earnings of politically connected firms. This study contributes to literature on the comparison of the earnings quality of politically connected firms using two different definitions of political connections. This paper also introduces the new proxy of political connections using politically exposed person. The rest of this paper is organized as follows. The second section will discuss literature review. Third section describes the financial and political connection data. Finally, we present the result and conclude.

\section{HYPOTHESIS DEVELOPMENT}

Until the end of Suharto reign, Indonesia is highly centralized and stable political structure [1]. A year after Soeharto stepped down Indonesia has had a multi-party system. Before 1999, there are only 3 parties participated in the elections. However, in the two legislative elections since the fall of the Soeharto regime, no political party has managed to win an overall majority of seats, resulting in coalition governments. Greater democracy in the postSuharto era has introduced new forms of corruption. There are now many more political parties and these also need money. Soeharto's dramatic fall in May 1998 created political vacuum, with weak institutions and lack of popular leaders. With the collapse of rigid centralized control, the state became increasingly disjointed and self-serving. Corruption, which elaborately well organized under Suharto, grew more random and unpredictable. The public clamored for "reformasi", which generally stood for freedom, justice, and prosperity.

In 2004, the faltering transition from President Suharto's three decades of authoritarian rule experienced a breakthrough with the decisive popular election of President Susilo Bambang Yudoyono. For the first time in its 59-year history, Indonesia's executive is directly accountable to the people. For the era of "reformasi", this innovation marks a new beginning after a long series of false starts. However, how is the improvement of Indonesia transparency (in general) and how is the quality of accounting earnings 
(transparency) for listed firms (in particular) politically connected firms in reformation era for Indonesia is still remain a question.

Prior studies have examined political connections as they are expected to provide benefits to firms. Faccio et al., [6] find that politically connected firms are more likely to be bailed out during economic crises. Several studies across different markets also show that firms with political connections gain preferential access to credit [[7], [8], [9], [10], [11]] Chaney, et al. [3] in their international study find that firms with political connections is associated with a lower quality of accounting earnings. Furthermore, they document that political connections have incremental explanatory power beyond country, regulatory and firm-specific ownership characteristics. Leuz and Oberholzer-Gee [2] find that for firms which closely related to Soeharto tend to access to foreign securities due to the difficulty reestablishing connections with a new government when their patrons fall from power. Firms with foreign securities attract the attention of foreign analysts and the international press coverage [[4], [5]]. This facts leads to the first research question examined in this study How is the quality of accounting earnings for firms which formerly closely related to Soeharto in reformation era?. This study expect that connected firms (SDI) will have better (or no difference) earnings quality than non-connected ones.

\section{H1: Firms with political connections (SDI) will have better (or not significantly different) earnings quality than non-connected ones}

Goldman, So, and Rocholl [12] find that in the country with strong legal system, companies that are connected to the winning party are significantly more likely to experience higher procurement contracts. Then, when the losing party regains their political power in the next period, in turn, they will experience an increase in procurement contracts significantly. This study suggests that the value of current political power is matter to their connection's benefit. Leus and Oberholzer-Gee [2] explain three reasons that wellconnected firms are less likely to have publicly traded debt or equity securities abroad. First, well-connected firms have access to preferential financing at home and therefore do not need to access foreign capital markets. Second, firms with political ties dislike the transparency and scrutiny that come with publicly traded securities. Third, foreign securities make it more difficult for insiders to extract private control benefits. They also argue that Firms with political ties dislike the transparency and scrutiny because high levels of public scrutiny

can

be difficult to reconcile with political favors of often dubious legality. This leads to the second research question examined in this study - do firms with politically exposed person as board director is associated with lower quality of accounting earnings?. This study expects to find that firms with connection (PEP) will have lower earnings quality than nonconnected ones.

\section{H2: Firms with political connections (PEP) will have lower earnings quality than non-} connected ones.

\section{DATA}

\subsection{Sample}

For initial board members data in Indonesia Stock Exchange (IDX) obtained from Indonesia Capital Market Data (ICMD) directory. The first definition of political connection data (SDI) is from Soeharto Dependency Index which used in Fisman [1] and Leuz and Oberholzer-Gee [2] to define firms which closely related to Soeharto. The second definition of political connection data is from updated version of politically exposed person (PEP) list data from Tjondro [13]. In this data, they define politically connected firms in two ways. First, if one (or more) board of directors in the firm is categorized as politically 
exposed person based on Bank of Indonesia definition. Second is State-owned Enterprise (SOE). This approach (board connections) has been previously used in cross-country studies (Faccio et al., 2006) and studies in other countries [[14], [15], [16]].We update this list by adding some additional companies which not included in their list. Finally, we obtain financial data from Osiris database which provide financial report information for all listed companies in Indonesia Stock Exchange (IDX). My sample period covers year 2006 to 2010 .

\subsection{Variables}

All variables definition used in this analysis are provided in this section. Dummy variables are used to identify firms with and without connected firms (SDI and PEP), SOE, and nonconnected firms. To measure earnings quality, I follow Chaney, et al., [3] which used performance adjusted current accruals measure (REDCA) to measure the quality of financial reporting. This method is developed by Ashbaugh, LaFond, and Mahyew [17]. REDCA is computed as the difference between total current accruals (TCA) and expected performance (i.e.,ROA) adjusted total current accruals (EPTCA). We also use sales growth, year, and industry ( 2 digits SIC code) as control variables. If the politically connected firm has positive relation with REDCA, it means that the accrual quality is high or in other words the quality of accounting earnings is low.

\section{EMPIRICAL ANALYSIS}

\subsection{Soeharto Dependency Index and quality of accounting earnings}

In this section, we use cross sectional samples to examine the quality of accounting earnings for firm which were formerly closely related to Soeharto during 2006-2010. To examine this issue, we employ ordinary least square (OLS) regression to see how quality of accounting earnings varies on the listed companies in Indonesia.

$R E D C A=\beta_{0}+\beta_{1}$ connected $+\beta_{2}$ sales growth $+\beta_{3}$ year $+\beta_{4}$ industry $+\varepsilon$

Table 1 shows the result of the quality of accounting earnings for firm which formerly closely related to Soeharto in 2006-2010. The result shows the political connections dummy has negative relation to the quality of accounting earnings. The firms which were formerly closely related to Soeharto have better accounting earnings relatively to other firms in the reformation era. However, it is insignificant.

This findings consistent with Leuz and Oberholzer-Gee [2] which find firms which closely related to Soeharto tend to access to foreign securities due to the difficulty reestablishing connections with a new government when their patrons fall from power. Therefore they need to access foreign securities which requires higher of public scrutiny (higher transparency).

Table 1. Soeharto Dependency Index and quality of accounting earnings.

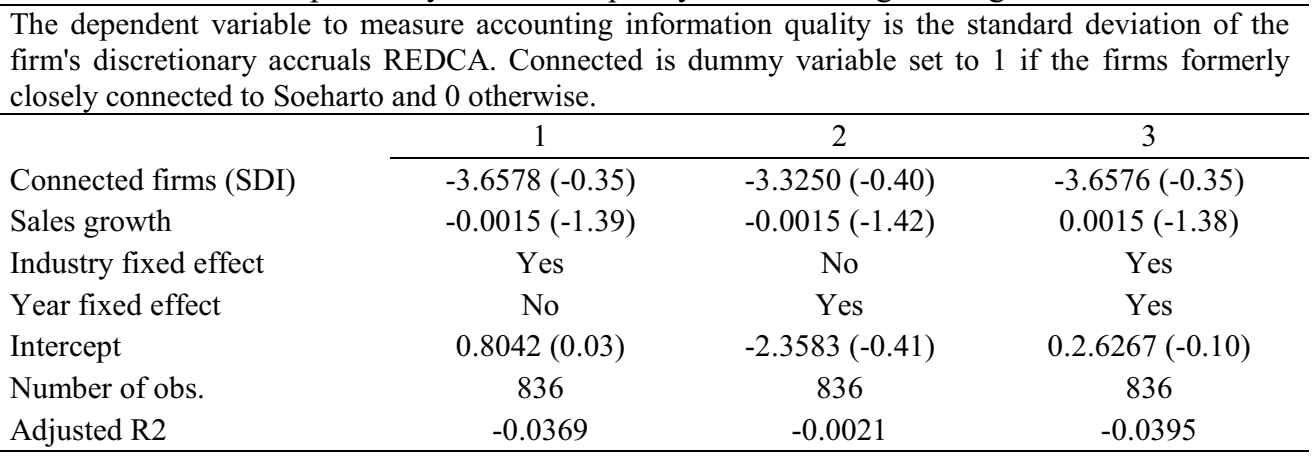




\subsection{Politically exposed person and quality of accounting earnings}

In the second section, we examine the quality of accounting earning using new set of political connections data based on politically exposed person who serve as board director in firms as a proxy. The objective of this test is to examine whether the quality of accounting earnings of politically connected firms in reformation era is become better or even worst. As we discussed earlier, in the political level, Soeharto's dramatic fall in May 1998 created political vacuum, with weak institutions and lack of popular leaders. With the collapse of rigid centralized control, the state became increasingly disjointed and selfserving. Corruption, which elaborately well organized under Suharto, grew more random and unpredictable.

Table 2 shows the relations between quality of accounting earnings and firms which have one or more politically exposed person. Surprisingly, after controlling some variables, we find that politically connected firms have significantly positive association with the quality of accounting earnings. This finding shows that politically connected firms are significantly have higher accrual quality or in other words is associated with lower quality of accounting earnings. This finding consistent with Goldman, So, and Rocholl [12] which find that in the country with strong legal system, firms that are connected to the winning party are significantly more benefit to their connection. It is also consistent with the explanation from Leus and Oberholzer-Gee [2] on why well-connected firms are less likely to have publicly traded debt or equity securities abroad. First, well-connected firms have access to preferential financing at home and therefore do not need to access foreign capital markets. Second, firms with political ties dislike the transparency and scrutiny that come with publicly traded securities. Third, foreign securities make it more difficult for insiders to extract private control benefits.

Table 2. Politically exposed person and quality of accounting earnings.

The dependent variable to measure accounting information quality is the standard deviation of the firm's discretionary accruals REDCA. Connected is dummy variable set to 1 if the firm has one (or more) politically exposed person as board of directors and 0 otherwise.

\begin{tabular}{lccc}
\hline & 1 & 2 & 3 \\
\cline { 2 - 4 } Connected firms (PEP) & $14.7739(2,06)$ & $10.4604(1.71)$ & $14.7963(2.06)$ \\
Sales growth & $-0.0015(-1.38)$ & $-0.0015(-1.37)$ & $-0.0015(-1.37)$ \\
Industry fixed effect & Yes & No & Yes \\
Year fixed effect & No & Yes & Yes \\
Intercept & $-16.4077(-.065)$ & $-5.0818(-0.81)$ & $-18.3816(-0.71)$ \\
Number of obs. & 800 & 800 & 800 \\
Adjusted R2 & -0.0326 & 0.0012 & -0.0353 \\
\hline
\end{tabular}

As additional test, we construct dummy variable for state-owned enterprise in the sample. Interestingly, when we include State-owned Enterprise (SOE) as politically connected firms, we find that the relations between SOE and the quality of accounting earnings still positive but insignificant. This finding show that SOE in Indonesia have better quality of accounting earnings than firms which have politically exposed person as a board of directors. Overall, consistent with prior findings, these findings give us the notion that the changes of political power structure also influence the quality of accounting earnings of politically connected firms. 


\section{CONCLUSION}

This paper examines the effect of changes in political power map to the quality of accounting earnings of politically connected firms in Indonesia in the reformation era (2006-2010). We employ two definitions as a proxy of political connections. First is Soeharto Dependency Index which classifying the firms which closely related to President Soeharto (old definition). Second is politically exposed person as a proxy of political connections (new definition). This study finds no difference between politically connected firms which formerly closely related to President Soeharto in 1998 and non-connected firms. Surprisingly, when we employ politically exposed person as board of directors as an indicator, we find that politically connected firms have significantly lower quality of accounting earnings. Additionally, this study also find interesting result that state-owned enterprise (SOE) have better quality of accounting earnings rather than firms with politically exposed person as a boards. Overall, consistent with prior findings, these findings give us the notion that the changes of political power structure also influence the quality of accounting earnings of politically connected firms. There are several limitations in this research. First due to time constrain of data collection, there are some others control variables such as market capitalization and operating cycle that have not been added into the model so far. Second, there are some missing variables in loans (which a part of REDCA calculations) data that might be influence the result. Third, there are still several other settings that might be developed as robustness checks such as the relation of number politically exposed person and the dependency index to the extent of financial opacity and employ some alternative measures the quality of accounting earnings.

\section{REFERENCES}

[1] Fisman, R. (2001). Estimating the Value of Political Connections. The American Economic Review, 91(4), 1095-1102.

[2] Leuz, C., \& Oberholzer-Gee, F. (2006). Political relationships, global financing, and corporate transparency: Evidence from Indonesia. Journal of Financial Economics, 81(2), 411-439.

[3] Chaney, P. K., Faccio, M., \& Parsley, D. (2011). The quality of accounting information in politically connected firms. Journal of Accounting and Economics, 51(1-2), 58-76.

[4] Baker, H. K., Nofsinger, J. R., \& Weaver, D. G. (2002). International Cross-Listing and Visibility. Journal of Financial \& Quantitative Analysis, 37, 495-521.

[5] Lang, M. H., Lins, K. V., \& Miller, D. P. (Writers). (2003). ADRs, Analysts, and Accuracy: Does Cross Listing in the United States Improve a Firm's Information Environment and Increase Market Value? [Article], Journal of Accounting Research

[6] Faccio, M., Masulis, R. W., \& McConnell, J. J. (2006). Political Connections and Corporate Bailouts. The Journal of Finance, 61(6), 2597-2635.

[7] Backman, M. (2001). Asian Eclipse: Exposing the Dark Side of Business in Asia (Revised edition ed.): John Wiley \& Sons.

[8] Claessens, S., Feijen, E., \& Laeven, L. (2008). Political connections and preferential access to finance: The role of campaign contributions. Journal of Financial Economics, $\boldsymbol{8 8}(3), 554-580$.

[9] Cull, R., \& Xu, L. C. (2005). Institutions, ownership, and finance: the determinants of profit reinvestment among Chinese firms. Journal of Financial Economics, 77(1), 117-146. [10] Johnson, S., \& Mitton, T. (2003). Cronyism and capital controls: evidence from Malaysia. Journal of Financial Economics, 67(2), 351-382. 
[11] Khwaja, A. I., \& Mian, A. (2005). Do Lenders Favor Politically Connected Firms? Rent Provision in an Emerging Financial Market*. Quarterly Journal of Economics, 120(4), 1371-1411. doi: 10.1162/003355305775097524

[12] Goldman, E., Rocholl, J., \& So, J. (2013). Politically Connected Boards of Directors and The Allocation of Procurement Contracts. Review of Finance, 17(5), 1617-1648. [13] Tjondro, E. (2012). Effect of Financial Leverage, Profitability, and Type of Bank Lending Decision using Political Tie as Moderating Variables. Master thesis, Airlangga University, Surabaya.

[14] Gray, S., Harymawan, I., \& Nowland, J. (2016). Political and government connections on corporate boards in Australia: Good for business?. Australian Journal of Management, 41(1), 3-26.

[15] Harymawan, Iman, and Nowland, J. "Political connections and earnings quality: how do connected firms respond to changes in political stability and government effectiveness?." International Journal of Accounting \& Information Management 24.4 (2016).

[16] Hillman, A. J. (2005). Politicians on the board of directors: Do connections affect the bottom line?. Journal of Management, 31(3), 464-481.

[17] Ashbaugh, H., LaFond, R., \& Mayhew, B. W. (2003). Do nonaudit services compromise auditor independence? Further evidence. The Accounting Review, 78(3), 611639. 